Internationale Zeitschrift für

\section{Bauinstandsetzen}

und Baudenkmalpflege

9. Jahrgang, Heft 4, 2003
International Journal for Restoration of Buildings

and Monuments

Vol. 9, No. 4, 2003

\title{
Inhalt / Contents
}

Editorial

D. Van Gemert, S. Ignoul, F. Van Rickstal, E. Toumbakari and L. Schueremans

Evolution of Structural Consolidation and Strengthening of Masonry in Belgium: Historical Overview and Case Studies

Entwicklung des konstruktiven Verstärkens und Festigens von Mauerwerk in Belgien: Historischer Überblick und Fallstudien

S. Ignoul, D. Van Gemert and F. Van Rickstal

Application of Mineral Grouts for Structural Consolidation of Historical Monuments

Anwendung mineralischer Feinmörtel zum Festigen von Tragwerken und von historischen Monumenten

L. Schueremans and D. Van Gemert

Safety Assessment and Design of Consolidation and Strengthening by Means of Injections

Sicherheitsanalyse und Planung einer verstärkenden und festigenden

Maßnahme durch Injizieren

L. Binda and A. Saisi

The Collapse and Reconstruction of the Noto Cathedral: Importance of the Investigation for the Design Choice Einsturz und Wiederaufbau der Kathedrale von Noto: Bedeutung durchgeführter Untersuchungen für die Planung des Wiederaufbaus

G.P.A.G. van Zijl and L.G.W. Verhoef

Double Sided Restrengthening of Historic Brickwork with Rods and Strips of Carbon Fibre Reinforced Plastic (CFRP)

Beidseitiges Festigen von historischem Mauerwerk mit Hilfe von Stäben und Streifen aus Kohlestoffaser verstärktem Kunststoff (CFRP) 


\section{Aus der Praxis/ Applications}

Volker Simon

Michel in altem Glanz

\section{Mitteilungen / Short Notes}

Enterprise IG Hamburg im Verbund mit externen Entwicklern gewinnt Materialica Design Award für Beschichtungssystem Albedo

100 Jahre Beratende Ingenieure in Deutschland

Jury ermittelte zum zweiten Mal die Preisträger der Dahlberg-Medaille

\section{Firmenmitteilungen / Companies Inform}

Neuer "Ratgeber Betoninstandsetzung" von Sakret

Verstärkung von tragenden Bauteilen mit Kohlefasern

Sanierung in Seifertshain: Stilechte Unikate für sächsische Kirche

Projekt Eiskeller - Beispiel einer gelungenen Denkmal-Sanierung

Neuerscheinungen / New Books

\section{WTA-Flash}

Aus den WTA-Referaten 